\title{
correspondence
}

\section{Physical science in Chile}

SIR,--My friend and former colleague Alwyn Eades, who recently spent three extremely busy weeks in Santiago, is reported (10 February, page 486) to have said that "it is very easy to be misleading about Chile and very easy to be misled". The truth of this statement is made patently clear by Eades' own article, "Three years after Allende", appearing in the same issue. The article is a mixture of factual information with some personal interpretations and political opinions; it also suffers from some important, and surely involuntary omissions. The unaware reader may find it difficult to distinguish between the first three of these and may not know about the latter; so he may easily be misled by an article which may easily be misleading, especially when the atypical front cover of the issue is politically leading.

Personal interpretations and political opinions are of course entirely subjective and Eades is entitled to make and have his own, but Nature is not the proper place to discuss them and I will not do so. I must, however, correct some of his most important omissions and errors lest it be thought that I and/ or the Chilean Physical Society share all of his views about what has happened to the physical sciences in Chile.

Eades' account of the development of physical research in Chile is in general accurate. When he writes, however, about the talks for "developing a science policy for Chile" in the early 1970s-which did in fact take place but led to nothing definitc--he fails to mention what had been done before and has been done since along these lines. $\mathrm{He}$ seems to ignore that the National Commission for Scientific and Technological Development (CONICYT), which was established before Allende in 1968 amongst other things to collaborate in developing such a policy, produced a draft for a National Plan for Scientific and Technological Development in 1974. This draft was carefully studied for several months by a committee in which an important role was played by a sizeable number of leading scientists (including several physicists) who were freely nominated by the universities and by the local Academy of Sciences. The outcome of the committee's work was a much improved version of the plan, which was officially approved by Chile's highest authorities early in 1976. These important omissions may leave the unaware reader of Eades' article under the wrong impression that the development of a science policy for Chile was completely abandoned after Allende and that no official steps had been taken before him.

When Eades writes about what has happened in the physics department of the Engineering School, where I work, he mentions "several waves of sackings for a mixture of political and economic reasons, as a result of which the number of academic staff has dropped from 45 to about 25"; he is wrong. So far there has been a reduction of only one member of staff (and this for economic reasons) and this affected four members of the department's academic staff: one of them had reached the minimum legal age to retire and had to do so and three of the youngest ones were transferred from full-time to half-time positions. The latter three preferred to resign and found jobs in other local institutions. Independently and at a later time, two other people left this department to work in the physics department in the Faculty of Sciences. Over the past three years, a few others have voluntarily taken posts abroad and some who were on study leave abroad chose not to come back. All this has taken the number of academic staff down to its present value of 32 .

It is true that four laboratories in this department lie virtually abandoned; but Eades fails to mention that three of these were never in full operation because of the shortage of staff (one of them was a one-man job) and that the fourth was almost abandoned when the Argentinian physicists who formed it were asked to leave the country before Allende's time. Eades also says about one of the Chilean Physical Society's present preoccupations, that "since all elections are prohibited in Chile, it (the Chilean Physical Society) is unable (like many other organisations) to replace those committee members who leave the country or retire", so he thinks that "it may shortly find itself with no committee at all". Elections are forbidden and this was one of our preoccupations while he was here. We have since found, however, that there are legal ways for scientific bodies such as the Socicties of Biology, Chemistry, Physics and Mathematics to renew their committees at their own free will and that some had in fact already done so. I am glad to inform him and your readers that we have now replaced one committee member who left the country and another who resigned, and that we are planning on renewing our committee early next year, when most of our membership will gather at the University of Concepción for the next scientific meeting.

Finally, I strongly disagree with Eades' statement that one side-effect of the coup was to set back physics research in Chile by nearly two decades. As his article rightly mentions, twenty years ago there was little or no research in physics in Chile: the first groups were just beginning to form, there was virtually no equipment, the Chilean Physical Society did not exist and the very idea of doing physics research in Chile was thought to be utopian by most. Whatever the results have been of the permanent brain drain from Chile over the past twenty years and the departure of scientists with every change of government, we are now much better off indeed than two decades ago. The large (by Chilean standards) number of scientific papers published in the last three years by Chilean physicists who are still working here is the best proof of this.

Yours faithfully,

Claudio Gonzalez

President,

Sociedad Chilena de Física, Chile

\section{Not rats, but mice}

Sir,-- We 'applied biologists' at the Pest Infestation Control Laboratory have been professionally associated with rats and mice for some thirty odd years, in all parts of the globe; I seem to have become our 'coprologer'

Thomas Jukes (10 February, page 491) has made a slight error: it is not rat faeces that are unscreenable from wheat kernels but mouse faeces. The principle is the same however. I agree with his point about 'filth' in foodit is nearly always purely an aesthetic objection sustainable in the 'developed' world-provided the food has been cooked!

It is a pity therefore that he didn't get that point accurately stated.

Yours faithfully,

R. A. Davis

Pest Infestation Control Laboratory,

Surbiton, Surrey, UK 